\title{
STUDY OF SOLID WASTE AND ASHES CONTENT OF RADIOACTIVE AND HEAVY METALS IN ASSIUT THERMAL POWER PLANT
}

\author{
Mahmoud F. Bady, Hassanien M. Hassanien ${ }^{b}$, Adel M. \\ Kamal El-Deen ${ }^{c}$ and A. M Hussein ${ }^{d}$, \\ a Mechanical Engineering Department, Faculty of Engineering, Assiut \\ University, Assiut (271516), Egypt. \\ ${ }^{b}$ Research and Development Sector, Assiut Power Plant, Assiut, Egypt. \\ ${ }^{c}$ Department of Chemistry, Faculty of Science, Assiut University, Assiut \\ (271516), Egypt. \\ ${ }^{d}$ Department of Chemistry, Faculty of Science, Al Azhar University, Assiut \\ 71524, Egypt.
}

(Received July 26, 2011 Accepted September 14, 2011)

\begin{abstract}
The combustion of heavy fuel oil concentrates a high content of heavy elements in the ashes. These elements are vanadium, calcium, magnesium, sulfur, sodium, zinc, iron, silicon, nickel, aluminum and manganese, and radioactive metals as uranium and thorium. These elements have dangerous environmental impacts. Also water treatment unit's produces solid wastes. Such wastes later enter the environment by different pathways producing adverse effects on the quality of life, so reduction of the amount of solid wastes to be discharged to the environment goes in accordance with Egyptian Environmental Legal solid wastes discharge Regulations and man's welfare.
\end{abstract}

KEYWORDS: Thermal power plant, Solid waste, Radioactive and Heavy Metals.

\section{INTRODUCTION}

Oil is the largest source of energy in Egypt providing close to $90 \%$ of all entire power needs. Where, most heavy oil is used as a fuel for electricity generating plants and its combustion produces fly and bottom ashes. Also, River Nile, constitute the main source of water used in electricity generating plants. Ashes from fuel oil combustion and suspended solids from the Nile constitute the major solid wastes from power plants in Egypt. Sludges and ashes that are produced during operation and combustion became a solid waste burden and contain toxic and hazardous wastes. Solid wastes from power plants can be classified into three categories; Fuel wastes (flyash, bottom ash) and chemical sludge (from water and wastewater treatment systems), of the two wastes, partial utilization of ash has been commonly practiced, as fill for roads, runways, construction sites, as cement and brick admixtures has become more commonly practiced. Some possible fly ash applications and utilizations are [1]:

$>$ As a Portland cement admixture or partial replacement.

$>$ As a light aggregate for producing lightweight concrete blocks and structural lightweight concrete. 
As road bed material, loose aggregate, soil stabilizer, clean fill, or soil nutrient.

$>$ Recovery of the metallic components of fly ash, such as aluminum, vanadium, titanium, and iron.

$>$ Production of mineral wool.

Both ashes from the flue-gas and boiler residue are fed to the agriculture growing area to enhance the soil, where the minerals in these ashes will increase crop growth and yield more food per acre [2]. Accordingly the main objective of the current study is to investigate the ash's constituents and assist in terminating the environmental impacts of the solid wastes from assiut power plant.

\section{ASHES:}

Fossil fuel combustion results in gaseous products, called flue gases, and non-gaseous non-combustible residues called ash. A portion of the ash is carried along with the flue gas; this portion is called fly ash. The remainder of the ash settles to the bottom of the furnace and is called bottom ash [1,3]. The amount and characteristics of each type of ash produced depends on the type of fuel and boiler. Coal produces a relatively large amount of both ashes, while oil produces little bottom ash but more fly ash, and gas produces little of either ash. Ash contains the non-combustible constituents of the fuel, many of which may be toxic. For example, fuel oil fly ash may contain vanadium and other noncombustible and potentially toxic chemicals that may have been in the oil. The recovery modes of vanadium from the vanadium-containing ashes of thermal power stations are shown that there is no single approach to directly recovering vanadium from various ashes, each ash needs its own leaching mode depending on its chemical and phase compositions [4]. Fossil fuel combustion results in concentration of most trace elements in ash by approximately 10 times the concentration in the original fuel [5].Waste samples were taken from bottom ash of oily fuelled combustion power plant, physical properties and chemical composition were investigated and the following elements were detected $\mathrm{V}, \mathrm{Ni}, \mathrm{Fe}, \mathrm{Cr}, \mathrm{Pb}$, and $\mathrm{Cd}$ [6]. A 1997 analysis by the U.S. Geological Survey (USGS) found that fly ash typically contained 10 to $30 \mathrm{ppm}$ of uranium, comparable to the levels found in some granitic rocks, phosphate rocks, and black shale [5]. The combustion of oil concentrates in the ashes those radioelements, which later enters the environment by different pathways producing adverse effects on the quality of man life. The concentration of radioelements varies greatly between oil fields, and then still requiring local survey studies in this area. The concentration of radioactivity and heavy metals in crude oil, fuel oil $\mathrm{N}^{\circ} 6$ and the ashes from power plants were determined; the analysis includes the two major thermoelectric power plants in Venezuela, Ricardo Zuluaga on the northern seaside of Caracas and Planta Centro on the littoral of Carabobo State. The study covers different samples: fuel oil $\mathrm{N}^{\circ} 6$, heavy and medium petroleum as well as fuel Oil $\mathrm{N}^{\circ} 6$ ashes. Gamma spectrometry was used for measuring $226 \mathrm{Ra}, 214 \mathrm{~Pb}, 214 \mathrm{Bi}, 228 \mathrm{Ac}, 212 \mathrm{~Pb}, 212 \mathrm{Bi}$, $208 \mathrm{Tl}$ and $40 \mathrm{~K}$, and heavy metallic cations were determined by ICP-MS, which also allows the direct determination of $232 \mathrm{Th}$ and $238 \mathrm{U}$ [7]. The reuse of fly ash as an engineering material primarily stems from its pozzolanic nature, spherical shape, and relative uniformity. Fly ash recycling includes usage in; Portland cement and grout, embankments and structural fill, waste stabilization and solidification, raw feed for cement clinkers, mine reclamation, stabilization of soft soils, road subbase, aggregate, 
flowable fill and mineral filler in asphaltic concrete, other applications include cellular concrete, roofing tiles, paints, metal castings, and filler in wood and plastic products $[8,9]$.

\section{SLUDGE:}

Sludge is a water-formed deposit that will settle, and may include all suspended solids (SS) carried by water. Generally physical treatment includes processes like filtration, sedimentation used to separate and concentrate various components of all suspended solids without chemically altering their form [10]. By physical treatment as a primary treatment, floating and suspended solids are settled and removed by sedimentation in clarifiers from raw water, where inorganic and organic suspended solids are settled out then blowdawn [11,12], if chemicals and coagulants are used, such as lime, alum and ferric sulfate, ferric chloride inorganic sludge will be generated; Sludge that settles to the bottom of the clarifier is blowdawn and pumped into a filter press for dewatering, solidification and stabilization, which reduce the mobility of pollutants in the environment thus making land disposal safer. Generally, solidification and stabilization technology is effective for inorganic waste, solidification refers to disposal techniques that convert a liquid, semi-solid, or finely divided solid particles into a stable solid. Sludge which is usually generated at 3 to 7 percent solids (by weight) is usually thickened and dewatered to 35 to 45 percent solids to reduce its volume then disposed of in a landfill [13].

\section{SPECIFICATIONS OF ASSIUT POWER PLANT}

The present study has been developed in Assiut electric power plant with a maximum power of $2 \times 312 \mathrm{MW} / \mathrm{h}$ Image (1); each unit is equipped with a high capacity steam boiler with 16 burners distributed in four floors, placed tangentially in the corners of the furnace to induce a vertical swirl motion of the combusting gases, and there are no flue gas desulphurization beds. Also there are a pre-treatment with capacity of 60 $\mathrm{m}^{3} / \mathrm{hr}$, waste water with capacity of $40 \mathrm{~m}^{3} / \mathrm{hr}$ for unit (I) and $60 \mathrm{~m}^{3} / \mathrm{hr}$ for unit (II), and filter press unit for both.

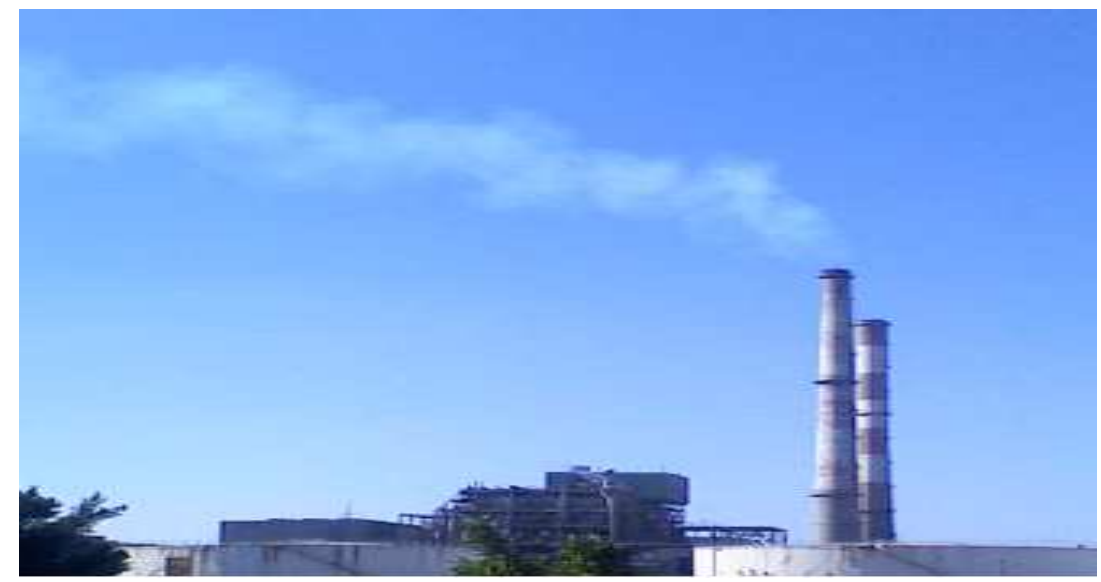

Image 1; Assiut thermal power plant 
The main parameters of the steam boiler are: steam power of 1024 ton/h (maximum), superheated steam pressure of 170 bars, and temperature of $540{ }^{\circ} \mathrm{C}$ for both as in Table (1).

Table 1; Specifications of the two units

\begin{tabular}{|l|c|c|c|c|}
\hline \multirow{2}{*}{ Item } & \multicolumn{2}{|c|}{ Unit (1) } & \multicolumn{2}{c|}{ Unit (2) } \\
\cline { 2 - 5 } & Designed & N. operation & Designed & N. operation \\
\hline Load MWh & 312 & 155 & 312 & 200 \\
Steam ton $/ \mathrm{h}$ & 1024 & 484 & 1024 & 671 \\
Fuel cons. $\mathrm{m}^{3} / \mathrm{h}$ & 70 & 35.8 & 78 & 51 \\
No. of burners & 16 & 12 & 16 & 12 \\
Steam temp. ${ }^{\circ} \mathrm{C}$ & 541 & 540 & 541 & 540 \\
Stack height & \multicolumn{2}{|c|}{$\varphi=5.13 \mathrm{~m}$} & \multicolumn{2}{c|}{$\varphi=4.9 \mathrm{~m}$} \\
Stack top width $(\varphi)$ & \multicolumn{2}{c|}{$120 \mathrm{~m}(+50 \mathrm{~m}$ from sea level $)}$, & $120 \mathrm{~m}(+50 \mathrm{~m}$ from sea level $)$, \\
\cline { 2 - 5 }
\end{tabular}

In Assiut power plant, burning of heavy fuel oils (Mazout) that contains high sulfur content (approximately $3.89 \%$ ), sodium (40.13 ppm) and high vanadium (approximately106.94 ppm), led to flue gases with obnoxious emissions, flyashes and bottom ashes. The physicochemical properties of the fuel to be used can be read in Table (2).

Table 2; Chemical analyses for fuel oil

\begin{tabular}{|c|c|c|c|c|c|c|c|c|c|c|c|}
\hline Test & $\begin{array}{c}\text { Ash } \\
\text { wt } \%\end{array}$ & $\begin{array}{l}\text { Asph. } \\
\text { wt } \%\end{array}$ & $\begin{array}{l}\mathrm{C} \\
\%\end{array}$ & $\begin{array}{l}\mathrm{H} \\
\%\end{array}$ & $\begin{array}{l}\mathrm{N} \\
\%\end{array}$ & $\begin{array}{c}\mathrm{Na} \\
\mathrm{ppm}\end{array}$ & $\begin{array}{l}\mathrm{S} \\
\%\end{array}$ & $\begin{array}{c}\mathrm{V} \\
\mathrm{ppm}\end{array}$ & $\begin{array}{c}\text { Wax } \\
\text { es wt } \\
\%\end{array}$ & $\begin{array}{c}\text { Gross } \\
\text { C.V. } \\
\text { Cal/gm }\end{array}$ & $\begin{array}{c}\text { Net } \\
\text { C.V. } \\
\text { Cal/gm }\end{array}$ \\
\hline Result & 0.069 & 2.0 & 83.8 & 11.5 & 0.65 & 40.13 & 3.89 & 106.94 & 3.7 & 10323 & 9740 \\
\hline Method & $\begin{array}{l}\text { ASTM. } \\
\text { D-482 }\end{array}$ & IP 143 & & $\begin{array}{l}\text { ASTM } \\
\text { D-5373 }\end{array}$ & & $\begin{array}{c}\text { SOLAAR } \\
\text { S4 }\end{array}$ & $\begin{array}{l}\text { ASTM. } \\
\text { D-1552 }\end{array}$ & $\begin{array}{c}\text { SOLAAR } \\
\text { S4 }\end{array}$ & IP 143 & \multicolumn{2}{|c|}{$\begin{array}{l}\text { ASTM. } \\
\text { D-4809 }\end{array}$} \\
\hline
\end{tabular}

Also, raw water used come from the River Nile, and contains the different suspended and dissolved solids as analyzed and shown in Table (3).

Table 3; Analysis results for River Nile dissolved solids (2009)

\begin{tabular}{|c|c|c|c|c|c|c|c|c|c|c|c|c|}
\hline Month & Jan & Feb & Mar & Apr & May & Jun & Jul & Aug & Sep & Oct & Nov & Dec \\
\hline $\mathrm{PH}$ & 8.88 & 8.80 & 8.53 & 8.57 & 8.44 & 8.34 & 8.30 & 8.76 & 8.95 & 8.73 & 8.8 & 8.86 \\
\hline Cond. $(\mu \mathrm{s} / \mathrm{cm})$ & 343 & 290 & 310 & 299 & 292 & 285 & 290 & 293 & 308 & 338 & 317 & 326 \\
\hline Tur.(NTU) & 4.10 & 3.40 & 3.20 & 2.25 & 2.47 & 2.50 & 2.31 & 2.77 & 4.10 & 4.41 & 2.8 & 3.75 \\
\hline $\mathrm{Cl}(\mathrm{ppm})$ & 15 & 14 & 10 & 10 & 10 & 8 & 10 & 10 & 11 & 12 & 13 & 13 \\
\hline $\mathrm{SiO}_{2}(\mathrm{ppm})$ & 2.10 & 1.93 & 3.12 & 2.86 & 3.71 & 5.53 & 6.52 & 4.42 & 3.22 & 0.26 & 3.1 & 2.16 \\
\hline $\mathrm{Na}(\mathrm{ppm})$ & 20 & 24 & 25 & 27 & 22 & 23 & 28 & 29 & 25 & 25 & 24 & 26 \\
\hline $\mathrm{Fe}(\mathrm{ppm})$ & 0.17 & 0.12 & 0.10 & 0.17 & 0.16 & 0.15 & 0.14 & 0.11 & 0.28 & 0.14 & 0.1 & 0.2 \\
\hline T. Hard. $\left(\mathrm{ppmCaCO}_{3}\right)$ & 122 & 110 & 118 & 118 & 110 & 108 & 111 & 110 & 110 & 112 & 114 & 126 \\
\hline Ca. H. & 76 & 72 & 72 & 74 & 68 & 70 & 71 & 70 & 70 & 62 & 72 & 74 \\
\hline Mg. H.Org. & 46 & 38 & 46 & 44 & 42 & 38 & 40 & 40 & 40 & 50 & 42 & 52 \\
\hline M.(ppmKMnO $\left.{ }_{4}\right)$ & 6.4 & 4.0 & 5.3 & 4.88 & 5.2 & 4.05 & 4.5 & 4.96 & 4.69 & 4.0 & 6.8 & 5.22 \\
\hline TSS (ppm) & 25 & 24 & 26 & 22 & 20 & 29 & 21 & 25 & 18 & 20 & 16 & 19 \\
\hline
\end{tabular}




\section{SOLID WASTES DISCHARGES' LAW}

A number of laws address solid waste management. The following laws apply to scrap and sludge from the WWTP [14]:

$>$ Law 38/1967 which addresses public cleanliness regulates the collection and disposal of solid wastes from houses, public places, commercial and industrial establishments.

$>$ Ministry of Housing, Utilities and Urban Communities (MHUUC) decree No. 134 of 1968, which provides guidelines from domestic and industrial sources, including specifications for collection, transportation, composting, incineration and land disposal.

$>$ Law 31/1976, which amended law 38/1967

$>$ Law 43/1979, the Law of Local administration, which provided that city councils are responsible for "physical and social infrastructure", effectively delegating responsibility for infrastructure functions.

$>$ Law 4/1994 regulates incineration of solid waste

\section{ASH ANALYSIS}

The ashes formed in different places in the steam generating unit at tubes surfaces, in the furnace bottom, flue gases and in the chimney, were gathered and chemically analyzed as in Table (4), analyzed by X-Ray diffraction as results show in Table (5) and analyzed for uranium and thorium by X-Ray diffraction and spectrophotometeric determination respectively Table (6).

Table 4 Chemical analysis of the ash

\begin{tabular}{|c|c|c|c|c|c|c|c|c|c|c|c|c|c|}
\hline $\begin{array}{l}\text { Chem. } \\
\text { Comp. }\end{array}$ & $\mathrm{SiO}_{2}$ & $\mathrm{Fe}_{2} \mathrm{O}_{3}$ & $\mathrm{NiO}$ & $\mathrm{CaO}$ & $\mathrm{MgO}$ & $\mathrm{Na}_{2} \mathrm{O}$ & $\mathrm{V}_{2} \mathrm{O}_{5}$ & $\mathrm{MnO}$ & $\mathrm{ZnO}$ & $\mathrm{Al}_{2} \mathrm{O}_{3}$ & $\mathrm{SO}_{4--}$ & \multicolumn{2}{|c|}{$\mathrm{Ash}$} \\
\hline$\%$ & 1.7 & 2.6 & 0.5 & 17.8 & 14.6 & 10.2 & 37.2 & 0.05 & 3.6 & 0.37 & 11.4 & 3.6 & 0.32 \\
\hline
\end{tabular}

Table 5 X-Ray diffraction of the ash

\begin{tabular}{|c|c|}
\hline Item & Dominant phase detected \\
\hline Ash sample & $\begin{array}{c}\mathrm{Na}_{2} \mathrm{SO}_{4}+\mathrm{Na}_{2} \mathrm{Ni}\left(\mathrm{SO}_{4}\right)_{2}+\mathrm{Na}_{6} \mathrm{Mg}\left(\mathrm{SO}_{4}\right)_{4}+\mathrm{MgSO}_{4}+\mathrm{Mg}_{2} \mathrm{~V}_{6} \mathrm{O}_{17}+\mathrm{CaSO}_{4}+\mathrm{Na}_{6} \\
\mathrm{Mg}_{3}\left(\mathrm{VO}_{4}\right)_{4}+\mathrm{Ni} \mathrm{SO}_{4}+\mathrm{NaV}_{6} \mathrm{O}_{15}+\mathrm{Na}_{2} \mathrm{Mg}\left(\mathrm{SO}_{4}\right)_{2}+\mathrm{Ni}_{3} \mathrm{~V}_{2} \mathrm{O}_{8}+\mathrm{Fe}_{4} \mathrm{~S}_{5} \mathrm{O}_{21} .\end{array}$ \\
\hline
\end{tabular}

Table 6 Radioactive metals in the ash

\begin{tabular}{|c|c|c|c|c|}
\hline \multirow{2}{*}{ Item } & \multicolumn{2}{|c|}{ Uranium } & \multicolumn{2}{c|}{ Thorium } \\
\cline { 2 - 5 } & $\begin{array}{c}\text { Furnace } \\
\text { Ash }\end{array}$ & $\begin{array}{c}\text { Chimney } \\
\text { Ash }\end{array}$ & $\begin{array}{c}\text { Furnace } \\
\text { Ash }\end{array}$ & $\begin{array}{c}\text { Chimney } \\
\text { Ash }\end{array}$ \\
\hline Concentration ppm & 450 & 50 & 400 & 20 \\
\hline
\end{tabular}




\section{SLUDGE DISCHARGE}

The pre-water and wastewater treatment plant generate sludge that settles to the bottom of the clarifiers by about $5 \%$ of the total production and with $40-50 \%$ solid that are pumped out to the thickener tanks in the wastewater units and the slurry then pumped into the filter press units for dewatering Image (2), Fig. (1). Water exits through the filter to the wastewater area drain pit and concentrated solids are screwed out and periodically removed and disposed of in a landfill.

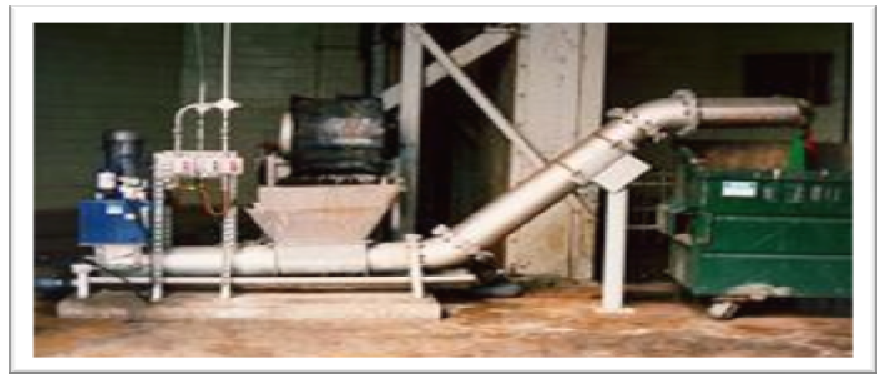

Image 2; Filter press unit

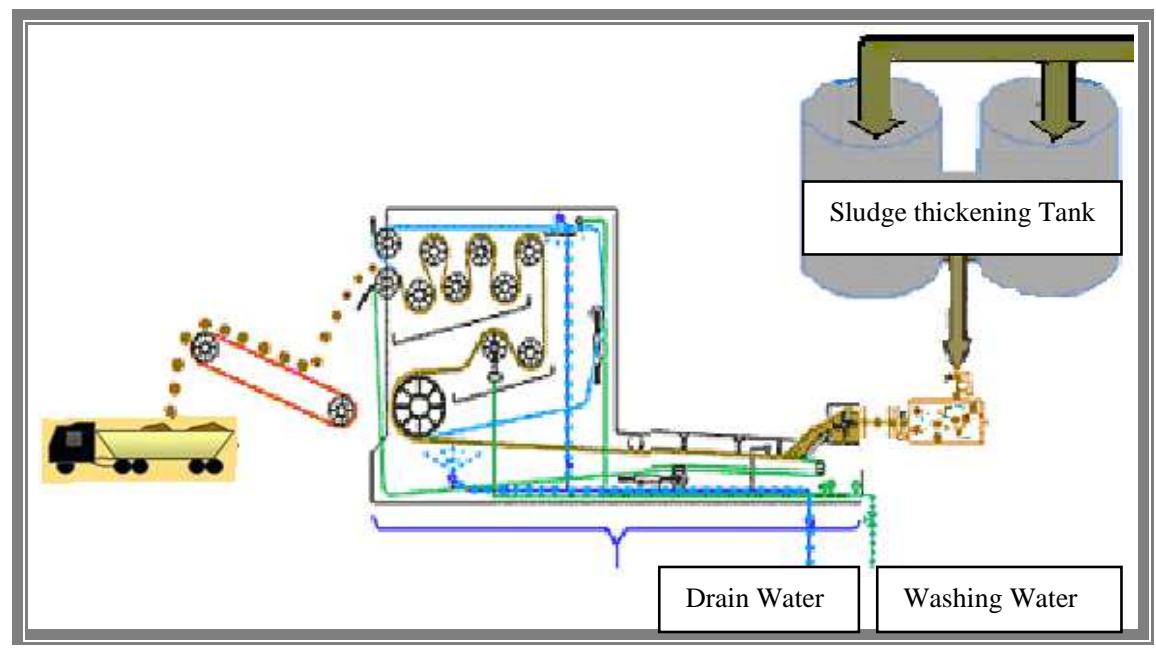

Figure1; Filter press unit

\section{DISCUSSION AND ANALYSIS}

\section{ASH}

As shown from the chemical analysis in Tables (3) and (4), there is high content of heavy elements as vanadium, calcium, magnesium, sulfur, sodium, zinc, iron, silicon, nickel, aluminum and manganese, and radioactive metals determination in Table (5), shows the presence of uranium and thorium and these elements has a dangerous environmental impact, so in the Assiut thermal power plant we informed the responsible of Egyptian Nuclear Authority, and they periodically brought their trucks 
when the units went in shutdown to take the ashes to be land filled at the healthy landfill at Alexandria province.

\section{SLUDGE}

The sludge from the filter press units, after solidification is collected and sends to the municipal solid waste landfill to be land filled.

\section{ENVIRONMENTAL IMPACTS}

With the arrangements that be taken by the responsible of Assiut Power Plant, no ash wastes will reach the outside environment, the on-site land impacts and off-site land impacts of ashes and sludge were almost reduced, also the bad toxicity impact of the heavy metals and the harmful radiation impact of radioactive uranium and thorium, which has adverse effects on the quality of man life were eliminated. Finally, reduction of the amount of solid wastes to be discharged to the environment goes in accordance with Egyptian Environmental Legal solid wastes discharge Regulations.

\section{CONCLUSION}

The combustion of heavy fuel oil concentrated a high content of heavy elements in the ashes. These elements are vanadium, calcium, magnesium, sulfur, sodium, zinc, iron, silicon, nickel, aluminum and manganese, and radioactive metals as uranium and thorium. Such elements have dangerous environmental impacts. Also water treatment unit's produced solid wastes. These wastes when entered the environment had adverse effects on the quality of life. So reduction of the amount of solid wastes that discharged to the environment went in accordance with Egyptian environmental legal solid wastes discharge regulations and man's welfare.

\section{REFERENCES}

1. Harza Consulting Engineers and Scientists, Chicago, Illinois, USA "Water Quality Improvement and Conservation Project,' Submitted to: United States Agency for International Development, Amman Chamber of Industry, Jordan, Ministry of Water and Irrigation, Jordan, December 1994, pp pp.17.

2. Nelson Leonard Nemerow, 'Industrial Waste Treatment,' Elsevier Science \& Technology Books, October 2006

3. Clean Air Task Force, the Land and Water Fund of the Rockies "'the Last Straw, Water Use by Power Plants in the Arid,' the Energy Foundation, the Hewlett Foundation, USA, April 2003, pp.5, Internet Available:

http://www.lawfund.org/ and http://www.catf.us/

4. Original Russian Text (C) M.V. Tsygankova, V.I. Bukin, E.I. Lysakova, A.G. Smirnova, A.M. Reznik, 2011, published in Izvestiya VUZ. Tsvetnaya Metallurgiya, 2011, No. 1, pp. 21-26, Internet Available:

https://springerlink3.metapress.com/content/0607t7u4h76qr100/resource

5. [5] U.S. Geological Survey (October, 1997), " Radioactive Elements in Coal and Fly Ash: Abundance, Forms, and Environmental Significance," (PDF), U.S. Geological Survey Fact Sheet FS-163-97, Internet Available: http://pubs.usgs.gov/fs/1997/fs163-97/FS-163-97.pdf 
6. Saeedi, M. and A.R. Bazkiaei, 2008.Characterization of thermal power plant fuel oil combustion residue. Res. J. Environ. Sci., 2: 116-123, Internet Available: http://scialert.net/abstract/?doi=rjes.2008.116.123.

7. H. Barros1, L. Sajo-Bohus, J.M. Abril and E.D. Greaves, "Radioactivity concentration and heavy metal content in fuel oil and oil-ashes in Venezuela," Radioprotection Volume 40, Number Suppl. 1, May 2005, pp. S183-S189, Internet Available:

http://www.radioprotection.org/index.php?option=com_article\&access=standard\&Itemid $=129 \& u r l=/$ articles/radiopro/abs/2005/02/p202/p202.html.

8. U.S. Environmental Protection Agency. "Using Coal Ash in Highway Construction - A Guide to Benefits and Impacts" (PDF), Internet Available: http://www.epa.gov/epaoswer/osw/conserve/c2p2/pubs/greenbk508.pdf.

9. U.S. Federal Highway Administration, "Flyash," Internet Available: http://www.fhwa.dot.gov/infrastructure/materialsgrp/flyash.htm

10. Use of Degraded Water Sources as Cooling Water in Power Plants, EPRI, Palo Alto, CA, and California Energy Commission, Sacramento, CA: 2003. 1005359.

11. Unified Facilities Criteria (UFC), "'Industrial water treatment operation and maintenance," U.S. army corps of engineers, Naval Facilities Engineering Command (Preparing Activity), Air Force Civil Engineer Support Agency, UFC 3-240-13FN 25 May 2005.

12. Cement Industry - Inspection Manual, June 2002, pp.32, Service Units, Water treatment units,

13. J. O'Hagan (PIER), K. Zammit (EPRI) 'Use of Degraded Water Sources as Cooling Water in Power Plants,' Final Report, Public Interest Energy Research Program (PIER), October 2003.

14. Egyptian Environmental Affairs Agency, Internet Available: http://www.eeaa.gov.eg.

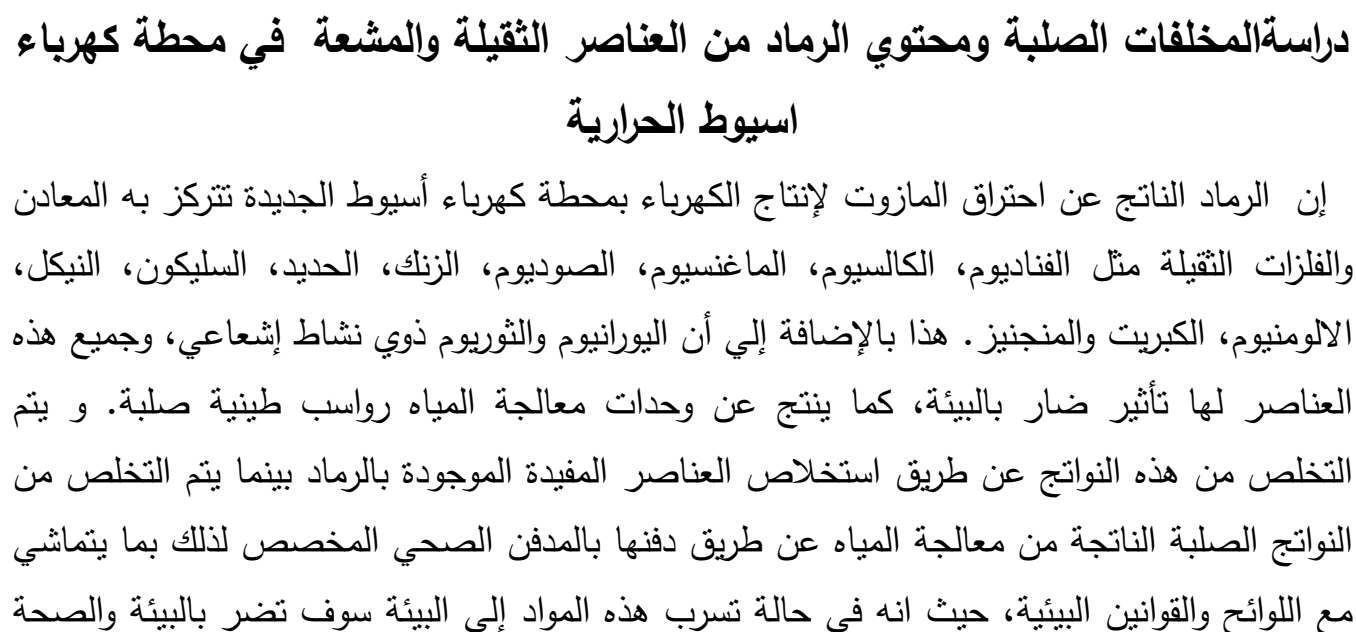

